\title{
Screening Cover Crops for Weed Suppression in Conservation Agriculture
}

\author{
Mutondwa M. Phophi ${ }^{1}$, Paramu L. Mafongoya ${ }^{1}$, Alfred O. Odindo ${ }^{1} \&$ Lembe S. Magwaza $^{1}$ \\ ${ }^{1}$ Department of Crop Science, School of Agricultural, Earth and Environmental Sciences, University of \\ KwaZulu-Natal, Private Bag X01, Scottsville, 3209, Pietermaritzburg, South Africa \\ Correspondence: Department of Crop Science, School of Agricultural, Earth and Environmental Sciences, \\ University of KwaZulu-Natal, Private Bag X01, Scottsville, 3209, Pietermaritzburg, South Africa. E-mail: \\ mutondiwa@gmail.com
}

Received: August 3, $2017 \quad$ Accepted: September 20, $2017 \quad$ Online Published: October 10, 2017
doi:10.5539/sar.v6n4p124
URL: https://doi.org/10.5539/sar.v6n4p124

\begin{abstract}
The use of herbicides amongst smallholder farmers is minimal because herbicides are expensive and they require specialized application equipments. Weeds are problematic in conservation agriculture where herbicides are expensive for smallholder farmers. The use of cover crops can help to suppress weed growth and development by creating an environment which is not suitable for weeds survival. Cowpea (Vigna unguiculata (L.) Walp) dolichos lablab (Lablab purpureus L.) and velvet bean (Mucuna pruriens (L.) DC) were evaluated for biomass accumulation and weed suppression under conservation agriculture system in two contrasting experimental sites: Ukulinga and Bergville in KwaZulu-Natal. Bare plot and herbicide treatments served as controls. Treatments were laid in a randomized complete block design, replicated three times. Mucuna pruriens (L.) DC had the highest biomass accumulation in both sites Bergville $(0.72 \mathrm{t} / \mathrm{ha})$ and Ukulinga $(1.59 \mathrm{t} / \mathrm{ha})$. Cowpea had the lowest biomass accumulation in Bergville (0.59 t/ha) and lablab was the lowest in Ukulinga ( $0.88 \mathrm{t} / \mathrm{ha})$. Lablab was effective in suppressing weed biomass in Bergville $(P<0.05)$. Cowpea performed best in suppressing weed biomass in Ukulinga $(P<0.05)$. The results suggest that cowpea and lablab can be effective for weed suppression and therefore can be recommended for use in conservation agricultural systems.
\end{abstract}

Keywords: weed dynamics, weed biomass, weed abundance, weed diversity

\section{Introduction}

Frequent tillage with a moldboard, which is normally called conventional tillage, may lead to soil degradation. This degradation is in form of soil erosion, soil compaction and destruction of soil aggregates (Hamza and Anderson, 2005). Land degradation can cause low crop yields and hence an interest by South African smallholder farmers to adopt conservation agriculture. Conservation agriculture is based on three principles which are minimum tillage, mulching and crop rotation (Sarker, et al., 2012). Conservation agriculture has a potential to improve crop yields, reduce soil erosion and improve soil fertility (Giller et al., 2009). However, weed management is a problem in conservation agriculture compared to conventional tillage. This is attributed to deep burial of weed seeds by conventional ploughing and reduced seed germination as compared to conservation agriculture which leaves weed seeds on the surface and allow weeds to germinate (Singh et al., 2015).

Perennial weeds are more problematic in conservation agriculture compared to conventional tillage (Mader and Biere, 2011). Weed control in conservation agriculture can be achieved by application of herbicides. However, continuous application of herbicides with the same mode of action can lead to weeds developing herbicide resistance (Vencil et al., 2012). The use of manual weeding using hand hoes can also be used to manage weeds in conservation agriculture. However, this is labor demanding. An alternative weed control mechanism could be to use cover crops. Cover crops can improve soil fertility through improving soil biological, chemical and physical properties (Dabney et al., 2001). Leguminous cover crops can also improve soil fertility through biological nitrogen fixation (Matusso et al., 2014). Cover crops are a cheaper option to smallholder farmers who have no resources to purchase inorganic fertilizers for crop production (Murungu, 2012). A number of leguminous cover crops have been screened for weed suppression. Cowpea has been identified as an effective cover crop for suppression of weed biomass and density (Bilalis et al., 2010). Its effectiveness is attributed to its prostrate growth habit which can reduce light interception by weeds and hence reduce weed germination and growth 
(Zaviehmaradat et al., 2013). Most of the studies conducted on cover crops have concentrated on conventional tillage systems in other countries other than South Africa. However, there are few studies which have documented performance of leguminous cover crops under conservation agriculture across different ecological zones in South Africa. Hence the objective of this study was to evaluate the effect of leguminous cover crops on weed suppression in two contrasting experimental sites in South Africa.

\section{Materials and Methods}

\subsection{Site Description}

The study was carried out in two contrasting areas (Bergville and Ukulinga) both situated in KwaZulu-Natal Province. The two sites differed in soil properties. Soil samples were taken prior to commencement of the study as shown in Table 1. Annual rainfall of Bergville was $643 \mathrm{~mm}$ and the temperature ranged from $19.3{ }^{\circ} \mathrm{C}$ to 27.9 ${ }^{\circ} \mathrm{C}$. Monthly rainfall and temperature data of Bergville could not be found. Monthly rainfall and temperature for Ukulinga are shown in Table 2.

Table 1. Soil chemical and physical properties in Bergville and Ukulinga

\begin{tabular}{lllllllll}
\hline Site & sand \% & silt \% & clay \% & $\mathrm{pH}(\mathrm{KCI})$ & Total N\% & Org C \% & $\mathrm{P}(\mathrm{mg} / \mathrm{kg})$ & $\mathrm{K}(\mathrm{mg} / \mathrm{kg})$ \\
\hline Bergville & 25 & 16 & 59 & 3.83 & 0.23 & 2.2 & 7.9 & 165 \\
Ukulinga & 38 & 26 & 36 & 4.80 & 0.23 & 2.5 & 13.59 & 133 \\
\hline
\end{tabular}

Table 2. Monthly rainfall and temperature in Ukulinga 2015

\begin{tabular}{lllllllll}
\hline & Jan & Feb & Mar & Apr & May & Jun & Jul & Aug \\
\hline Min temperature ${ }^{\circ} \mathrm{C}$ & 16.03 & 15.60 & 15.68 & 12.02 & 11.88 & 8.93 & 8.94 & 10.92 \\
Max Temperature ${ }^{\circ} \mathrm{C}$ & 27.66 & 26.47 & 27.04 & 23.90 & 25.96 & 22.20 & 21.13 & 24.51 \\
Rainfall mm & 132.80 & 143.00 & 82.20 & 0 & 5.02 & 2.02 & 32.99 & 3.04 \\
\hline
\end{tabular}

\subsection{Experimental Design}

Three leguminous cover crops were evaluated for weed suppression and weed biomass accumulation. The cover crops were cowpea, velvet bean and lablab. The treatments were laid in a randomized complete block design, replicated three times. Bare plot and herbicide treatments served as control were no cover crops were grown.

\subsection{Land Preparation and Crop Management}

Each plot size was $10 \mathrm{~m}$ x $5 \mathrm{~m}$. Glyphosate was applied once in herbicide treatment at a rate of $1.5 \%$ per $10 \mathrm{~L}$. The maize and cover crops were planted at the same time in holes opened up by a hand hoe. Planting was done during the second week of January 2015. The maize cultivar used was Nelson's Choice open pollinated variety, planted at a spacing of $75 \mathrm{~cm} \times 35 \mathrm{~cm}$. All cover crops were planted at a spacing of $15 \mathrm{~cm} \times 30 \mathrm{~cm}$ to create a dense cover. Superphosphate fertilizer (10.2) was applied during planting according to the recommended rates of $20 \mathrm{~kg} / \mathrm{ha}$ in Ukulinga and $55 \mathrm{~kg} / \mathrm{ha}$ in Bergville. Weeding was done once by hand hoeing after 4 weeks of planting. Urea $(46 \% \mathrm{~N})$ was applied two days after weeding at a recommendation of $120 \mathrm{~kg} / \mathrm{ha}$ to maize crops. Maize planted in Bergville did not germinate. In Ukulinga the maize germinated. However, there was no yield collected due to uncontrollable circumstance of wild pigs that fed on the maize crop.

\subsection{Sampling and Data Analysis}

Soil samples were taken to a depth of $15 \mathrm{~cm}$ prior to commencement of study for analysis. The dry matter production for cover crops was determined at 8,12 and 16 weeks after planting. The potential of the cover crops to suppress weeds was determined by measuring the weed biomass at 8,12 and 16 weeks after planting. Both the weed biomass and cover crop biomass were estimated from a sample by harvesting the above-ground vegetative growth in a quadrat of $0.5 \mathrm{~m}^{2}$ that was placed randomly on three sampling points in each plot. The weed samples were oven dried at $70{ }^{\circ} \mathrm{C}$ for 72 hours. The cover crops were oven dried at $70{ }^{\circ} \mathrm{C}$ for 72 hours for biomass estimation. Weed species counts were measured and harvested within the $0.5 \mathrm{~m}^{2}$ quadrat. Weed species were identified according to their growth habit using their biological nomenclature.

Weed biomass, cover crop biomass, weed species richness, weed species diversity and abundance were square root transformed before analysis to meet the assumption of ANOVA. Weed biomass and cover crop biomass were subjected to Genstat $14^{\text {th }}$ edition for analysis of variance (ANOVA). Weed species diversity was calculated using Shannon-Wiener diversity index. Weed species richness was calculated using Margalef Index (Margalef, 1958). Least significance difference (LSD) was used to detect mean differences amongst the treatments at $P \leq$ 
0.05

\section{Results and Discussion}

\subsection{Cover Crop Biomass Accumulation}

There was no significant interaction between treatments and sampling time in both sampling sites $(P>0.05)$. Cover crop biomass showed significant difference across treatments in both sampling sites $(P<0.05)$. All the cover crops did not produce more than 2t/ha of biomass in both sites. In Bergville, velvet bean had the highest biomass and it was significantly different to cowpea and lablab (Table 3). The highest biomass accumulation by velvet bean was attributed to its robust growth habit which allowed it to do best in acidic soils. This relates well to the results found by Malama and Kondowe (2002) who reported that velvet bean appears to be ideal for high biomass accumulation in acidic soils. Teasdale et al. (2007) also supports that velvet bean is well adapted to dry hot conditions. Although Cowpea is said to be well adapted in acidic soils it gave the lowest biomass accumulation in Bergville.

Table 3. Cover crop biomass accumulation in Bergville and Ukulinga (t/ha)

\begin{tabular}{lll}
\hline Treatment & Bergville & Ukulinga \\
\hline Cowpea & 0.59 & 0.98 \\
Lablab & 0.65 & 0.88 \\
Velvet bean & 0.72 & 1.59 \\
SE & 0.03 & 0.30 \\
LSD $(P \leq 0.05)$ & 0.05 & 0.39 \\
\hline
\end{tabular}

\subsection{Weed Species Identified}

Different weed species were observed and identified in this study. The weed species ranged from annual to perennial types. Ukulinga had 32 weed species and Bergville had 14 weed species. The most dominant weeds in Ukulinga were: Oxalis latifolia H.B.K, Bidens pilosa L., and Commelina benghalensis L. According to the results, these weeds were found to be more competitive in Ukulinga. In Bergville the most dominant weeds were: Acanthospermum australe (loefl.) Kuntze, Leucas martinicensis $\mathrm{R} . \mathrm{Br}$ and Cleome monophylla L. and according to the farmers evaluation, these weeds are found to be more competitive in this area.

\subsection{Weed Biomass}

There was significant difference with weed biomass between treatments and sampling time $(P<0.05)$ (Table 4$)$. Lablab performed best in weed suppression in Bergville. It had the lowest weed biomass across all weeks. Although the soil was acidic, lablab produced a canopy cover more rapidly than the other cover crops and it managed to suppress weeds across all sampling times. This agrees with Frageria et al. (2009) who reported that lablab is tolerant to low soil $\mathrm{pH}$ and this gives it a chance to outcompete weeds for limited resources required for growth and development. It was followed by cowpea which also showed low weed biomass across sampling times. Cowpea had a prostrate growth condition that smothered weeds. Teasdale et al. (2007) reported that cowpea can grow vigorously and it is well adapted to hot climatic conditions. Herbicide did not perform well in suppressing weeds and this resulted from poor herbicide application.

Table 4. Weed biomass in Bergville (t/ha)

\begin{tabular}{llll}
\hline & \multicolumn{3}{l}{ Time of sampling } \\
\hline Treatment & week 8 & week 12 & week 16 \\
Bare plot & 0.98 & 1.29 & 1.40 \\
Cowpea & 0.63 & 0.80 & 0.48 \\
Lablab & 0.47 & 0.58 & 0.32 \\
Velvet bean & 0.74 & 0.94 & 0.61 \\
Herbicide & 0.62 & 1.16 & 1.28 \\
SE & 0.17 & & \\
LSD $(P \leq 0.05)$ & 0.29 & & \\
\hline
\end{tabular}

There was no significant interaction between treatment and sampling times in weed species biomass in Ukulinga $(P>0.05)$. Weed species biomass was significantly different across treatments $(P<0.05)$ (Table 5). Cowpea had the lowest weed species biomass but was not significantly different to lablab and velvet bean. Its effectiveness to suppress weeds was influenced by its ability to make a dense cover much faster than the other cover crops and 
this showed considerable reduction of weed biomass. In twelve weeks after planting, cowpea reduced weed biomass and due to observations, the yellow nutsedge had changed its color to brownish as a result of lack of sufficient light reception.

Table 5. Weed biomass in Ukulinga ( $\mathrm{t} / \mathrm{ha})$

\begin{tabular}{ll}
\hline Treatment & Weed Biomass \\
\hline Bare plot & 0.84 \\
Cowpea & 0.53 \\
Lablab & 0.60 \\
Velvet bean & 0.65 \\
Herbicide & 0.92 \\
SE & 0.24 \\
LSD $(P \leq 0.05)$ & 0.23 \\
\hline
\end{tabular}

\subsection{Weed Species Abundance}

There was no significant difference with weed species abundance across treatments in Bergville $(P>0.05)$. Treatments showed significant difference in weed species abundance in Ukulinga $(P<0.05)$ (Table 6). Cowpea had the least weed species abundance and it was followed by lablab. These two cover crops managed to suppress weed abundance better than other treatments.

Table 6. Weed species abundance in Bergville and Ukulinga

\begin{tabular}{lcl}
\hline \multicolumn{3}{l}{ Weed species abundance } \\
\hline Treatment & Bergville & Ukulinga \\
Bare plot & 2.34 & 6.13 \\
Cowpea & 1.97 & 4.63 \\
Lablab & 1.72 & 5.43 \\
velvet bean & 2.28 & 6.30 \\
Herbicide & 1.75 & 8.01 \\
SE & 0.59 & 1.58 \\
LSD $(P \leq 0.05)$ & 0.59 & 1.58 \\
\hline
\end{tabular}

Dominant weed species in Ukulinga were evenly distributed across the treatments (Table 7). Cowpea reduced the total weed species abundance (counts). Cowpea was effective in reducing Oxalis latifolia H.B.K. Lablab was effective in reducing Commelina benghalensis L. Bidens pilosa L. was effectively suppressed by velvet bean. Lablab and cowpea formed a better cover that managed to reduce the number of oxalis latifolia H.B.K and Bidens pilosa L. Although Oxalis latifolia H.B.K was evenly distributed, its difficulty to be effectively reduced by other cover crops could have resulted due to its growth habit. Oxalis latifolia H.B.K is a perennial weed that produces asexually by stolons, underground bulbs and tubers (Marshall, 1987). This type of reproduction makes it more competitive than other weeds.

Table 7. Dominant weed species abundance in Ukulinga

\begin{tabular}{llllll}
\hline \multicolumn{5}{c}{ Treatment } \\
\hline Species & Bare plot & Cowpea & Lablab & Velvet bean & Herbicide \\
B. pilosa L. & 3.0 & 1.6 & 1.7 & 2.3 & 1.1 \\
C. benghalensis L. & 2.1 & 0.9 & 0.5 & 1.5 & 1.1 \\
O. latifolia H.B.K & 32.4 & 23.8 & 32.7 & 43.4 & 78.9 \\
SE & & 28.04 & & & \\
LSD $(P \leq 0.05)$ & & 26.34 & & & \\
\hline
\end{tabular}

There was significant difference with weed species abundance across treatments in Bergville (Table 8). Acanthospermun australe (loefl.) Kuntze was the highest in abundance. This weed species did not show significant difference between sole maize, cowpea and lablab. Velvet bean had the highest abundance of Acanthospermum australe (loefl.) Kuntze. Cleome monophylla L. and Leucas martinicencis R.Br did not show any significant difference across treatments. However, cowpea was the most effective in reducing the abundance of Cleome monophylla L. and Leucas martinicenesis R.Br. 
Table 8. Dominant weed species abundance in Bergville

\begin{tabular}{llllll}
\hline & \multicolumn{5}{c}{ Treatment } \\
\hline Species & Bare plot & Cowpea & Lablab & velvet bean & Herbicide \\
A. australe & 3.81 & 3.37 & 2.74 & 4.33 & 1.96 \\
C. monophylla & 0.44 & 0.15 & 0.26 & 0.44 & 0.22 \\
L. martinicensis $\mathrm{R} . \mathrm{Br}$ & 0.15 & 0.15 & 0.19 & 0.52 & 1.00 \\
SE & & 1.24 & & & \\
LSD $(P \leq 0.05)$ & & 1.15 & & & \\
\hline
\end{tabular}

\subsection{Weed Species Diversity}

In Bergville, bare plot showed no significant difference across sampling time. In cowpea treatment the order was week $16=$ week $12>$ week 8 . For lablab the order was week $12>$ week $8>$ week 16 . Velvet bean did not show any significant difference between week 8 and week 12 . However, week 16 had the lowest weed species diversity. In herbicide treatment the order was week 16>week $12=$ week 8 . During sampling times lablab and cowpea had significant lower weed species diversity than the rest of the treatments. Week 12 showed no significant difference across treatments. At week 16 lablab and velvet bean had significantly lower weed species diversity compared to the rest of the treatments. Lablab and cowpea effectively suppressed weed species diversity compared to other treatments due to its prostate growth habit.

Table 9. Weed species diversity in Bergville

\begin{tabular}{llll}
\hline & \multicolumn{3}{l}{ Time of sampling } \\
\hline Treatment & week 8 & week 12 & week 16 \\
\hline Bare plot & 1.02 & 1.01 & 1.04 \\
Cowpea & 0.87 & 1.06 & 0.99 \\
Lablab & 0.80 & 1.04 & 0.65 \\
Velvet bean & 0.95 & 1.04 & 0.62 \\
Herbicide & 0.92 & 0.95 & 1.06 \\
SE & 0.12 & & \\
LSD $(P \leq 0.05)$ & 0.11 & & \\
\hline
\end{tabular}

Weed diversity in Ukulinga showed significant difference between treatment and sampling time $(P<0.05)$ (Table 10). Bare plot showed significant difference over time. The least weed species diversity was found in week 12 (1.28 species) and the highest was found in week 16 (1.39 species). Cowpea had the least weed species diversity in week 12 (0.93 species) which was significantly different to week 16 (1.05 species) and week 8 (91.05 species). Lablab treatment had the least weed species diversity in week 16 ( 0.57 species $)$ and the highest weed species diversity was found in week 8 (1.13 species). Velvet bean had the least weed species diversity in week 16 ( 0.54 species) and the highest was found in week 8 ( 0.99 species). Herbicide treatment had the least weed species diversity in week 8 ( 0.84 species) and the highest weed species was found in week 16 (1.16 species).

Cowpea and lablab had a prostrate growth habit and this could have resulted in shading light for weed development. This could be the main reason why these two cover crops had lower weed species diversity compared to velvet bean which had a creepy growth habit. The prostrate growth of these two cover crops could have also competed for soil moisture with weeds and hence reduce weed species diversity as was pointed by Hutson (1997) and Mulder et al. (2001) that low soil moisture has negative impact on weed diversity. Herbicide was applied once as pre emergence. This could have led to high weed species diversity. Tuesca and Puricelli (2007) reported that glyphosate herbicide is more effective when applied with other herbicides. Mavunganidze et al. (2014) also found that glyphosate was more effective when applied in combination with other herbicides. However, this was not the case in this study, hence high weed species diversity was found under herbicide treatment. 
Table 10. Weed species diversity in Ukulinga

\begin{tabular}{llll}
\hline & \multicolumn{3}{l}{ Time of sampling } \\
\hline Treatment & week 8 & week 12 & week 16 \\
\hline Bare plot & 1.16 & 1.28 & 1.39 \\
Cowpea & 1.05 & 0.93 & 1.05 \\
Lablab & 1.13 & 0.97 & 0.57 \\
Velvet bean & 0.99 & 0.75 & 0.54 \\
Herbicide & 0.84 & 0.97 & 1.16 \\
SE & 0.11 & & \\
LSD $(P \leq 0.05)$ & 0.10 & & \\
\hline
\end{tabular}

\subsection{Weed Species Richness}

Weed species richness showed significant difference across sampling times $(P<0.05)$ (Table 11). Week 8 had the lowest species richness and was significantly different to week 16 . The increase of weed species richness in week 12 and week 16 could have been affected by seasonal variability (rainfall and temperature).

Table 11. Weed species richness in Bergville

\begin{tabular}{ll}
\hline Sampling time & weed species richness \\
\hline week 8 & 0.30 \\
week 12 & 0.40 \\
week 16 & 0.58 \\
SE & 0.51 \\
LSD $(P \leq 0.05)$ & 0.21 \\
\hline
\end{tabular}

There was significant interaction between treatments and sampling times in Ukulinga $(P<0.05)$ (Table 12). There was no significant difference with weed species richness in week 8 and week 12 . However, week 16 had significantly higher weed species richness compared to week 8 and week 12. The same trend was observed in velvet bean. Cowpea did not show any significant difference across sampling times. Herbicide had the highest weed species richness in week 16 which was not significantly different from week 12 . Week 8 was significantly different from week 16 but not from week 12. At sampling times week 8 did not show any significant difference across the treatments. At week 12 velvet bean had the lowest weed species richness compared to herbicide and bare plot. At week 16 weed species richness was in the order of bare plot $>$ herbicide. Cowpea $=$ lablab $=$ velvet bean.

Cowpea and lablab had a consistent weed species richness reduction over sampling times. The prostrate growth habit of these two cover crops could have resulted in the reduction of light interception by weeds which is essential for growth and development.

Table 12. Weed species richness in Ukulinga

\begin{tabular}{llll}
\hline \multicolumn{4}{l}{ Sampling Time } \\
\hline Treatment & week 8 & week 12 & week 16 \\
\hline Bare plot & 0.90 & 0.97 & 1.48 \\
Cowpea & 0.60 & 0.48 & 0.30 \\
Lablab & 0.98 & 0.64 & 0.16 \\
Velvet bean & 0.82 & 0.41 & 0.16 \\
Herbicide & 0.61 & 0.97 & 1.05 \\
SE & 0.45 & & \\
LSD $(P \leq 0.05)$ & 0.42 & & \\
\hline
\end{tabular}

\section{Conclusion and Recommendation}

Cowpea and lablab were adapted to the two agro ecological zones under which the cover crops were screened. They were also very effective in weed suppression due to their prostrate growth habit. Although these cover crops produced high biomass, they may have a potential to reduce maize grain yield in intercropping systems with maize due to competition for growth resources. However, velvet bean produced the highest biomass but it was not effective in weed suppression. This is attributed to its creeping growth habit. Hence poor weed control. 
Therefore in screening cover crops for weed suppression, the growth habit seems to be more important than the production of biomass. Cowpea and lablab can be highly recommended for use in conservation agriculture. In this research we screened very few cover crops. There is need to screen a wide range of leguminous cover crops under different agro ecological conditions. The effect of planting dates on cover crop biomass production, maize yield and weed suppression in maize cropping systems should be evaluated. The impact of cover crops on improvement of soil biological, chemical and physical properties should be evaluated. The management of cover crop biomass through mulching or incorporation into the soil and its impact on weed dynamics and soil fertility improvement needs to be evaluated.

\section{Acknowledgement}

The study was supported by National Research Foundation through the South African Research Chair: Agronomy and Rural Development at the University of KwaZulu-Natal, in South Africa. We would like to thank Bergville farmers for providing us with land and field trial management.

\section{References}

Bilalis, D., Papastylianou, P., Konstantos, A., Patsiali, S., Karkanis, A., \& Efthimiadou, A. (2010). Weed-suppressive effects of maize-legume intercropping in organic farming. International Journal of Pest management, 56, 173-181. https://doi.org/10.1080/09670870903304471

Dabney, S. M., Delgado, J. A., \& Reeves, D. W. (2001). Using winter cover crops to improve soil and water quality. Communication in Soil Science and Analysis, 32, 1221-1250. https://doi.org/10.1081/CSS-100104110

Frageria, N. K., Baligar, V. C., \& Li, Y. C. (2009). Differential soil acidity tolerance of tropical legume cover crops. Communications in Soil Science and Plant Analysis, 40, 1148-1160. https://doi.org/10.1080/00103620902754127

Giller, K. E., Witter, E., Corbeels, M., \&Tittonell, P. (2009). Conservation agriculture and smallholder farming in Africa: The heretics' view. Field Crops Research, 114, 23-34. https://doi.org/10.1016/j.fcr.2009.06.017

Hamza, M. A., \& Anderson, W. K. (2005). Soil compaction in cropping systems a review of the nature, causes and possible solutions. Soil \& Tillage Research, 121-145. https://doi.org/10.1016/j.still.2004.08.009

Hutson, M. A. (1997). Hidden treatments in ecological experiments: Re-evaluating the ecosystem function of biodiversity. Oecologia, 110, 449-460. https://doi.org/10.1007/s004420050180

Mader, P., \& Berner, A. (2011). Development of reduced tillage systems in organic farming in Europe. Renewable Agriculture and Food Systems, 27, 7-11. https://doi.org/10.1017/S1742170511000470

Malama, C., \& Kondowe, K. (2003). Performance of green manures and grain legumes on severly acidic soils in Northern Zambia, and their effect on soil fertility improvement: In Waddington, S.R (ed) Grain legumes and green manures for soil fertility in Southern Africa: taking stock of progress. Proceedings of a Conference held 8-11 October 2002 at the Leopard Rock Hotel, Vumba, Zimbabwe. Soil Fert Net and CIMMYT-Zimbabwe 185-196

Margalef, R. (1958). Information theory in ecology. Gen. Systems, 3, 36-71

Marshal, G. (1987). A review of the biology and control of selected weed species in the genus Oxalis:O. Stricta L., O. Latifolia H.B.K and O. Pes-carae L. Crop Protection, 6, 355-363. https://doi.org/10.1016/0261-2194(87)90068-8

Matusso, J. M. M., Mugwe, J. N., \& Mucheru-muna, M. (2014). Potential role of cereal-legume intercropping systems in intergrated soil fertility management in smallholder farming systems of Sub-Saharan Africa. Journal of Agriculture and Environmental Management, 3, 162-174

Mavunganidze, Z., Madakadze, I. C., Nyamangara, J., \& Mafongoya, P. L. (2014). The impact of tillage system and herbicide on weed density, diversity and yield of cotton (Gossipium hirsutum L.) and maize (Zea mays L.) under the smallholder sector. Crop Protection, 58, 25-32. https://doi.org/10.1016/j.cropro.2013.12.024

Mulder, C. P. H., Uliassi, D. D., \& Doak, D. F. (2001). Physical stress and diversity- productivity relationships: The role of positive interactions. Proc. Natl. Acad. Sci. USA, 98, 6704-6708. https://doi.org/10.1073/pnas.111055298

Murungu, F. S. (2012). Conservation agriculture for smallholder farmers in the Eastern Cape province of South Africa: recent developments and future prospects. African Journal of Agricultural Research, 7, 5278-5284. 
Murungu, F. S., Chiduza, C., \& Muchaonyerwa, P. (2010). Biomass accumulation, weed dynamics and nitrogen uptake by winter cover crops in a warm-temperate region of South Africa. African Journal of Agricultural Research, 5, 1632-1642

Sarker, K. K., Xiaoyan, W., Hongwen, L., Chunlin, X., Wenying, L., Jin, H., Jeff, E. R., Rasaily, R. G., \& Xiadong, Q. (2012). Development Strategies of small scale conservation farming practices on two wheeled tractor in Bangladesh. African Journal of Agricultural Research, 7, 3747-3756.

Singh, H. P., Batish, D. R., \& Kohli, R. K. (2003). Allelopathic Interactions and allelochemicals: new possibilities for sustainable weed management. Critical Reviews in Plant Sciences, 22, 239-311. https://doi.org/10.1080/713610858

Teasdale, J. R., Brandsaeter, L. O., Calegari, A., \& Neto, F. S. (2007). Cover crops and weed management: Non chemical weed management: principles, concepts and technology. CAB International

Tuesca, D., \& Puricelli, E. (2007). Effect of tillage systems and herbicide treatments on weed abundance and diversity in a glyphosate resistant crop rotation. Crop Protection, 26, 1765-1770. https://doi.org/10.1016/j.cropro.2007.03.008

Vencil, W. K., Nichols, R. L., Webster, T. M., Soteres, J. K., Mallory-Smith, C., Burgos, N. R., \& McClelland, M. R. (2012). Herbicide resistance: toward an understanding of resistance development and the impact of herbicide resistant crops. Weed Science, 60, 2-30. https://doi.org/10.1614/WS-D-11-00206.1

Zaviehmavadat, L., Mazaheri, D., Majnon, H. N., \& Rezaei, M. (2013). The effect of Maize and Cowpea Intercropping on weed control condition. International Journal of Agronomy and Plant Production, 4, 2885-2889.

\section{Copyrights}

Copyright for this article is retained by the author(s), with first publication rights granted to the journal.

This is an open-access article distributed under the terms and conditions of the Creative Commons Attribution license (http://creativecommons.org/licenses/by/3.0/). 